\title{
Correction to: Terpene synthase genes in Melaleuca alternifolia: comparative analysis of lineage-specific subfamily variation within Myrtaceae
}

\author{
Jed Calvert ${ }^{1} \cdot$ Abdul Baten $^{1} \cdot$ Jakob Butler ${ }^{2} \cdot$ Bronwyn Barkla $^{1} \cdot$ Mervyn Shepherd $^{1}$ (i)
}

Published online: 5 February 2021

(c) Springer-Verlag GmbH Austria, part of Springer Nature 2021

\section{Correction to: Plant Syst Evol (2018) 304:111-121 https://doi.org/10.1007/s00606-017-1454-3}

Publisher's Note Springer Nature remains neutral with regard to jurisdictional claims in published maps and institutional affiliations.

In the methods on page 112, we report a "cytological" estimate of $710 \mathrm{Mb}$ based on flow cytometry for Melaleuca alternifolia. For clarity, this should have been qualified as a "2C" or diploid estimate of genome size.

Furthermore the last paragraph of the online resource 2 should read; "The $1 \mathrm{C}$ genome size estimate from flow cytometry of $\underline{355 \mathrm{Mb}}$ was similar to the estimate of $356 \mathrm{Mb}$ based on sequencing."

The original article can be found online at https://doi.org/10.1007/ s00606-017-1454-3.

Mervyn Shepherd

mervyn.shepherd@scu.edu.au

1 Southern Cross Plant Science, Southern Cross University, Lismore, NSW 2480, Australia

2 School of Biological Science, University of Tasmania, Hobart, TAS 7005, Australia 